\title{
Effect of replacement of corn starch by whey protein isolate in biodegradable film blends obtained by extrusion
}

\author{
Viviane Machado Azevedo ${ }^{a}, *$, Soraia Vilela Borges ${ }^{a}$, José Manoel Marconcini ${ }^{b}$, \\ Maria Irene Yoshida ${ }^{c}$, Alfredo Rodrigues Sena Neto ${ }^{b}$, Tamara Coelho Pereira ${ }^{a}$, \\ Camila Ferreira Gonçalves Pereira ${ }^{a}$ \\ a Food Science Department, Federal University of Lavras (UFLA), 37200-000, Lavras, MG, Brazil \\ ${ }^{\mathrm{b}}$ National Agricultural Nanotechnology Laboratory, Embrapa Instrumentação, São Carlos, 13560-970, SP, Brazil

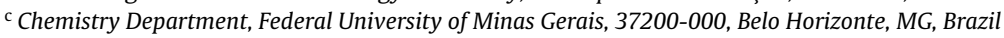

\section{A R T I C L E I N F O}

\section{Article history:}

Received 19 July 2016

Received in revised form 9 October 2016

Accepted 15 October 2016

Available online 17 October 2016

\section{Keywords:}

Polymers

Blends

Extrusion

Thermal stability

Morphological properties

\begin{abstract}
A B S T R A C T
The aim of this study was to evaluate the effect of replacing corn starch by whey protein isolated (WPI) in biodegradable polymer blends developed by extrusion. X-ray diffraction showed the presence of a Vh-type crystalline arrangement. The films were homogeneous, indicating strong interfacial adhesion between the protein and the thermoplastic starch matrix (TPS) as observed in scanning electron microscopy. The addition of WPI on TPS matrix promoted an increase in the thermal stability of the materials. It was observed 58.5\% decrease in the water vapor permeability. The effect of corn starch substitution by WPI on mechanical properties resulted in a more resistant and less flexible film when compared the TPS film. The addition of WPI caused greenish yellow color and less transparent films. The substitution of corn starch by WPI made it possible to obtain polymer blends with improved properties and represents an innovation for application as a packaging material.
\end{abstract}

(C) 2016 Published by Elsevier Ltd.

\section{Introduction}

Serious environmental pollution caused by synthetic plastics has led to increased research directed towards biodegradable plastics. The integral use of renewable resources and hydrocarbon reduction has aroused interest in developing alternatives to replace, totally or partially, the synthetic polymers by biodegradable polymers, mainly for food products (Ma, Chang, Yu \& Stumborg, 2009; Ortega-Toro, Jiménez, Talens \& Chiralt, 2014; Yan, Hou, Guo \& Dong, 2012). Thus, films and coatings formed from biodegradable polymers, such as polysaccharides, proteins and lipids, have been studied due to their environmental benefits and sustainability (Hong \& Krochta, 2003; Ramos, Fernandes, Silva, Pintado \& Malcata, 2012; Redl, Morel, Bonicel, Guilbert \& Vergnes, 1999; Sharma \& Luzinov, 2013).

In biodegradable plastics development, starch has been considered one of the most promising materials (Ma, Chang, Yu \& Stumborg, 2009), among natural biopolymers, due to its low cost, non-toxicity, biodegradability and easy availability (Aydın \& Ilberg,

\footnotetext{
* Corresponding author.

E-mail address: vmachadoazevedo@gmail.com (V.M. Azevedo).
}

2016; Fajardo, Martins, Fuciños, Pastrana, Teixeira \& Vicente, 2010; Šimkovic, 2013; Gross \& Kalra, 2002; Wang, Chang \& Zhang, 2010). It is composed of amylose and amylopectin in amounts that vary according to plant source, for example, corn starch has about $28 \%$ amylose while tapioca starch has $17 \%$. In general, an increasing amount of amylose improves the mechanical, barrier and film formation properties, as well as the processing conditions (Forssell, Lahtinen, Lahelin \& Myllärinen, 2002; Mendes et al., 2016; Raquez, Nabar, Srinivasan, Shin, Narayan \& Dubois, 2008). In addition, starch has the ability to form a continuous matrix and has thermoplastic characteristics, which allows it to be easily processed (Bertuzzi, Vidaurre, Armada \& Gottifredi, 2007; Ortega-Toro, Jiménez, Talens \& Chiralt, 2014; Shah, Bandopadhyay \& Bellare, 1995; Yan, Hou, Guo \& Dong, 2012).

The thermoplastic starch (TPS) is one of the materials studied in the development of biodegradable materials (Chen, Zhang, Zhang, Fan \& Wu, 2012; Curvelo, De Carvalho \& Agnelli, 2001; López, Zaritzky, Grossmann \& García, 2013; Ma, Chang, Yu \& Stumborg, 2009; Teixeira, Da Roz, Carvalho \& Curvelo, 2007). Starch becomes thermoplastic, when processed with plasticizers under high temperature and mechanical forces, with rupture of the granules and subsequent fusion (de Graaf, Karman \& Janssen, 2003; Herrera Brandelero, Victoria Eiras Grossmann \& Yamashita, 2011). It can 
easily be utilized in synthetic polymer processes, such as extrusion, blowing, injection and compression molding (Averous \& Boquillon, 2004; Teixeira et al., 2007). Currently, there are several products obtained from TPS (López et al., 2013; Ma, Chang, Yu \& Stumborg, 2009; Shamekh, Myllärinen, Poutanen \& Forssell, 2002), however, the development of TPS films is still limited due to its fragility, low water resistance and dependence on the mechanical properties and environmental moisture (Averous \& Boquillon, 2004; Bastos, Santos, da Silva \& Simão, 2009; López et al., 2013; Zullo \& Iannace, 2009). Thus, in order to compensate for these disadvantages, the starch may be blended with other polymers (Aydın \& Ilberg, 2016; Shi et al., 2008).

If compared to other common proteins like gluten, soy or other biopolymers, whey protein has been studied for packaging applications due to its abundant availability (50 million tons of unprocessed whey per year) (Schmid et al., 2012), transparency, flexibility and possessing good aroma and oxygen and lipid barrier properties. However, these films have a low moisture barrier, thermal stability and traction properties (McHugh \& John, 1994; Prommakool, Sajjaanantakul, Janjarasskul \& Krochta, 2011).

In general, films made from a single polymer have shown good properties in some aspects and bad in others. Therefore, the use of biopolymer mixtures has become an alternative to improve biodegradable film performance properties (Yan, Hou, Guo \& Dong, 2012). As such, films obtained by the combination of polysaccharides (starches, alginates, cellulose and chitosan) with protein (milk protein, soy protein, collagen and gelatin) have been developed (Cheng et al., 2003; Ferreira, Nunes, Delgadillo \& Lopes-da-Silva, 2009; García, Cova, Sandoval, Müller \& Carrasquel, 2012; Haider, Park \& Lee, 2008; Leuangsukrerk, Phupoksakul, Tananuwong, Borompichaichartkul \& Janjarasskul, 2014; Mariani, Allganer, Oliveira, Cardoso \& Innocentini-Mei, 2009; Pereda, Aranguren \& Marcovich, 2008; Sun, Sun \& Xiong, 2013) and showed better properties when compared those obtained from the pure polymers.

Research has been conducted on proteins and polysaccharides blends, but nothing has been reported about the combination of corn starch and whey protein isolate. As a novel alternative to the food industry for increase the potential use of a by-product of the dairy industry for application as a packaging material, or other plastic stuffs with suitable performance properties, the objective of this study was to evaluate the effect of the replacement of corn starch by whey protein isolate in films produced by extrusion on structural, thermal, morphological, mechanical, optical and barrier properties.

\section{Experimental}

\subsection{Material}

Corn starch (Amidex 3001), with 70\% amylose and 30\% amylopectin, was obtained from Corn Products Brazil (Balsa Nova, PR, Brazil). Whey protein isolate (WPI 9410) with 90\% protein was obtained from Hilmar Ingredients (Hilmar, CA, USA). Glycerol, stearic acid and granulated anhydrous citric acid were from Cargill (Uberlândia, MG, Brazil).

\subsection{Preparation of TPS/WPI blends films}

Corn starch and whey protein isolate (TPS/WPI) blends were obtained from the mixture of the following components: solid phase: $60 \%$ (TPS/WPI) and liquid phase: $24 \%$ glycerol and $16 \%$ water. To the final mixture, $1 \mathrm{wt} \%$ stearic acid and $1 \mathrm{wt} \%$ citric acid was also added, which act as anticaking agent and antioxidant, respectively. The blends were developed by replacing corn starch (TPS) by whey protein isolate (WPI) in the solid phase (60\%) as shown in Table 1.
Table 1

Symbols of TPS/WPI of blend films developed.

\begin{tabular}{lll}
\hline & \multicolumn{2}{l}{ Solid phase (60\%) } \\
\cline { 2 - 3 } Code & TPS $(\%)$ & WPI (\%) \\
\hline TPS & 100 & 0 \\
TPS90/WPI10 & 90 & 10 \\
TPS80/WPI 20 & 80 & 20 \\
TPS70/WPI 30 & 70 & 30 \\
TPS60/WPI 40 & 60 & 40 \\
TPS50/WPI 50 & 50 & 50 \\
\hline
\end{tabular}

The mixture was processed in a Coperion extruder, model ZSK 18 , with $\mathrm{L} / \mathrm{D}=40$, co-rotating twin screw, $18 \mathrm{~mm}$ diameter screws with mixing and conducting elements, with 7 heating zones and 2 degassing zones. The screw speed was $300 \mathrm{rpm}$ and the temperature profile was $80,80,90,90,100,110$ and $110^{\circ} \mathrm{C}$. Once the pellets of these materials were obtained, they continued for processing in a single-screw AX Plastics extruder to obtain the sheets of film. The screw speed was $35 \mathrm{rpm}$ and the temperature profile was 85, 90 and $95^{\circ} \mathrm{C}$ in the three heating zones. Then the sheets were pressed at $115^{\circ} \mathrm{C} \pm 5^{\circ} \mathrm{C}$ for $3 \mathrm{~min}$ in a hydraulic press ( 15 ton capacity). The pressing conditions were: 3 ton/30s, 10 s without pressing; 6 ton for $3 \mathrm{~min}$. After pressing, the film sheets, $12 \times 12 \mathrm{~cm}$, were cooled to room temperature. Table 1 shows the composition of each film and each component amount (starch and whey protein isolate).

\subsection{Film conditioning and thickness}

The films were conditioned under controlled temperature, at $23 \pm 2{ }^{\circ} \mathrm{C}$ and $50 \pm 5 \%$ relative humidity (RH) for $48 \mathrm{~h}$ prior to testing, according to ASTM D618-00 (ASTM, 2000a). The film average thickness was measured by readings at ten different points, randomly taken in each test body, using a digital micrometer Mitutoyo (0.01 mm precision, Mitutoyo Sul-Americana, Suzano, SP, Brazil).

\section{4. $X$-ray diffraction $(X R D)$}

The corn starch, whey protein isolate and film X-ray diffractograms were obtained on a Shimadzu XRD-6000 machine (Shimadzu, Tokyo, Japan) equipped with Cu- $\mathrm{k}_{\alpha 1}(\lambda=1.5406 \AA$ ) filter radiation. Samples were mounted on aluminum stubs and analyzed with a step of $0.02^{\circ} \mathrm{s}^{-1}, 2 \theta$ from $4^{\circ}-40^{\circ}$, speed of $1^{\circ} \mathrm{min}^{-1}$ and $30 \mathrm{kV}, 30 \mathrm{~mA}$. The interlayer spacing (d) was calculated by the Bragg equation, (Equation (1)):

$\operatorname{sen} \theta=n \lambda / 2 d$

Where: $\boldsymbol{\lambda}$ corresponds to the wavelength used $(\boldsymbol{\lambda}=1.5406 \AA)$ and $\boldsymbol{\theta}$ (theta) is the angle where the peak is detected on the diffractogram.

\subsection{Scanning electron microscopy (SEM)}

The morphology of powdered components (corn starch and WPI) and film was investigated in a JSM 6510 JEOL (Peabody, Massachusetts, USA) scanning electron microscope with an accelerating voltage of $10 \mathrm{kV}$. Surface images were obtained from powdered components and from the cryogenic fracture of the extruded material. Fractured films were mounted on stubs with carbon tape, coated in gold under vacuum for $90 \mathrm{~s}$ (metallization), attached to the microscope and photomicrographed.

\subsection{Thermogravimetric analysis (TG)}

The thermal stability of the corn starch and WPI powder and of the films was evaluated by thermogravimetric analysis on a TGA 
Q500 equipment (TA Instruments, New Castle, USA). The analyzes were performed under a synthetic air atmosphere at a $40 \mathrm{~mL} \mathrm{~min}^{-1}$ flow rate, heating from $25^{\circ} \mathrm{C}$ to $600^{\circ} \mathrm{C}$ at a rate of $10^{\circ} \mathrm{C} \mathrm{min}-1$.

\subsection{Differential scanning calorimetry (DSC)}

Differential scanning calorimetry (DSC) was performed on a TA 60 DSC calorimeter (Shimadzu Corporation, Kyoto, Japan). Sample weight ranged between 2 and $5 \mathrm{mg}$ and an empty capsule was used as a reference. The heating and cooling ramps for the powdered WPI were set at $10^{\circ} \mathrm{C} \cdot \mathrm{min}^{-1}$ and varied between $-50^{\circ} \mathrm{C}$ and $250^{\circ} \mathrm{C}$. For powdered starch, ramps were set at $2^{\circ} \mathrm{C}$. $\mathrm{min}^{-1}$ and varied between $-80^{\circ} \mathrm{C}$ and $50^{\circ} \mathrm{C}$. For the film evaluations, the heating and cooling ramps were set at $10^{\circ} \mathrm{C} \mathrm{min}^{-1}$, the and sequence being: heating from 25 to $190^{\circ} \mathrm{C} / 10 \mathrm{~min}$, isothermic, to eliminate the thermal history; cooling from 190 to $-70^{\circ} \mathrm{C}$; and a second heating until $190^{\circ} \mathrm{C}$ (ASTM, 2003a). From the DSC curves, the glass transition temperature $\left(\mathrm{T}_{\mathrm{g}}\right)$ was measured in the second heating.

\subsection{Mechanical properties}

The film tensile properties of the films, tensile strength $\left(\sigma_{\max }\right)$, elongation at break $(\epsilon)$ and elastic modulus (EM), were measured according to ASTM D882-02 standard method (ASTM, 2002), in a EMIC DL3000 Universal Testing Machine (EMIC, São Paulo, Brazil) with $500 \mathrm{~N}$ load cell ( $50 \mathrm{Kgf}$ ). Samples of films were cut into strips $(10 \mathrm{~mm} \times 100 \mathrm{~mm})$ and the initial separation of the grips was $70 \mathrm{~mm}$ with a $50 \mathrm{~mm} \cdot \mathrm{min}^{-1}$ speed. The puncture of the films was carried out in a texture analyzer (Stable Microsystems, TATX2i model, England). The films were cut into $9 \mathrm{~cm}^{2}$ squares and fixed on a support with a central opening $(2.1 \mathrm{~cm}$ diameter $)$. A $5.0 \mathrm{~mm}$ diameter spherical probe $(\mathrm{P} / 5 \mathrm{~S}$ probe) was perpendicularly displaced towards the film surface at a constant speed of $0.8 \mathrm{~mm} . \mathrm{s}^{-1}$ until the probe passed through the film (Azevedo, Dias, et al., 2015; Chen \& Lai, 2008). The puncture strength/thickness $(\mathrm{N} / \mathrm{mm})$ was calculated by dividing strength at break by the film thickness to eliminate the effect of the thickness variation. Film deformation $(\mathrm{mm})$ was determined at the breaking point (Azevedo, Dias, et al., 2015; Park \& Zhao, 2004). For the tensile and puncture tests, five specimens for each film in three repetitions were used.

\subsection{Water vapor permeability (WVP)}

The water vapor permeability (WVP) the films was determined according to ASTM E96 method (ASTM, 2000b). The film was fixed in a polymethylmethacrylate (Plexiglas) capsule with four screws, symmetrically located around the circumference of the capsule with silicone grease, to ensure that the permeation takes place only through the film. Silica was added to the interior of the capsule. The permeation capsule was then placed in a chamber with controlled humidity and temperature at $25 \pm 2{ }^{\circ} \mathrm{C}$ and maintained at $75 \%$ relative humidity $(\mathrm{RH})$. The samples were weighed until constant weight was reached and the weight gain values were plotted as a function of time. The film WVP $(\mathrm{g} /(\mathrm{m} \cdot \mathrm{s} \cdot \mathrm{Pa}))$ was calculated according to Equation (2):

$W V P=(W V T R . \delta) / \Delta P$

where $\delta$ is the film thickness, WVTR is the water vapor transmission rate and $\Delta \mathrm{P}$ represents the difference in vapor pressure between the two faces of the film: $\Delta \mathrm{P}=\mathrm{S} \cdot(\mathrm{R} 1-\mathrm{R} 2)$; $\mathrm{S}$ is the saturated vapor pressure at the test temperature ( $2809 \mathrm{kPa}), \mathrm{R}_{1}$ is the $\mathrm{RH}$ outside the capsule (75\%) and $\mathrm{R}_{2}$ is the $\mathrm{RH}$ inside the capsule that contained silica $(0 \%)$.

\subsection{Optical properties}

The film color was measured in a Konica Minolta CR-400 (Osaka, Japan) machine, using the $\mathrm{CIE}\left(\mathrm{L}^{*}, \mathrm{a}^{*}, \mathrm{~b}^{*}\right)$ system with a D65 light source, $10^{\circ}$ observer angle and reflectance mode. The analyzed parameters were: $\left(\mathrm{L}^{*}, \mathrm{a}^{*}, \mathrm{~b}^{*}\right)$, chroma saturation index and hue angle. The results were expressed as the mean of ten readings on three replicates. The transparency of the films was determined by measuring the transmittance percentage $(\% \mathrm{~T})$ at $600 \mathrm{~nm}$ using UV/VIS 1601PC spectrophotometer (Shimadzu, Tokyo, Japan) according to the D1746-03 method (ASTM, 2003b). Transparency $\left(\mathrm{T}_{600}\right)$ was calculated by Equation (3), where $\delta$ is the film thickness.

$\boldsymbol{T}_{600}=(\boldsymbol{L o g} \% \boldsymbol{T}) / \delta$

\subsection{Statistical analysis}

The results of water vapor permeability (WVP) and mechanical and optical properties were evaluated using analysis of variance (ANOVA) with a 5\% level of significance, using STATISTICA SOFTWARE (VER. 8, STAT SOFT INC., TULSA, USA). X-ray diffraction (XRD), scanning electron microscopy (SEM), thermal gravimetric analysis (TG) and differential scanning calorimetry (DSC) were submitted to descriptive analysis.

\section{Results and discussion}

\subsection{X-ray diffraction $(X R D)$}

The X-ray diffraction patterns of the starch and powdered WPI are shown in Fig. 1. Fig. $1 \mathrm{a}$ presents peaks around $2 \theta=14.2^{\circ}$;

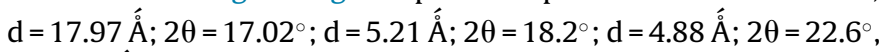
$\mathrm{d}=3.94 \AA$ Á, for the corn starch powder characteristic of an A-type crystalline arrangement. Previous studies have reported that waxy maize starch granules have an A-type crystalline arrangement, which has two weak diffraction peaks at $10.1^{\circ}$ and $11.5^{\circ}$; a peak of strong intensity at $15.3^{\circ}$; a double peak at $17.1^{\circ}$ and $18.2^{\circ}$ and a final peak of high intensity at $23.5^{\circ}$ (Angellier, Molina-Boisseau, Dole \& Dufresne, 2006; Kim, Han, Kweon, Park \& Lim, 2013). The diffractogram of the powdered WPI showed a possible amorphous structure which indicates the absence of lactose crystals in the WPI (Fig. 1b). The lactose present in the liquid whey during the drying process transforms into an amorphous state (Azevedo, Dias, et al., 2015; Nijdam, Ibach, Eichhorn \& Kind, 2007). Thus, lactose removal and subsequent drying of the liquid whey during the concentration process to WPI or to whey protein concentrate (WPC) makes the products amorphous.

Fig. 1c shows the X-ray diffraction patterns of the TPS/WPI films in the region of $2 \theta=4-34^{\circ}$. The $X$-ray diffraction pattern of the TPS film showed peaks around $2 \theta=12.6^{\circ} ; \mathrm{d}=7.02 \AA$ Á; $2 \theta=19.56^{\circ} ; d=4.54 \AA$ 的 $2 \theta=22.08^{\circ} ; d=4.03 \AA$ (Fig. 1c). The peak around $2 \theta=19.56^{\circ}$ is attributed to the recrystallization induction process in a simple helical amylose molecule during cooling after processing and corresponds to the Vh-type crystalline arrangement. Starch amylose and lipids are also responsible for the Vh-type crystallite complex formations at high melting temperatures, being also resistant to enzyme attack (Magalhães \& Andrade, 2009; de Campos et al., 2013). The Vh-type crystalline arrangement consists of an amylose recrystallization induced by lysophospholipids and complexes that form agents such as isopropanol and glycerol (Teixeira et al., 2011).

Peaks around $2 \theta=16.08^{\circ}$ are characteristic of amylopectin recrystallization (B-type crystallization) due to the presence of granules after extrusion (Teixeira et al., 2011). Thus, the films devel- 

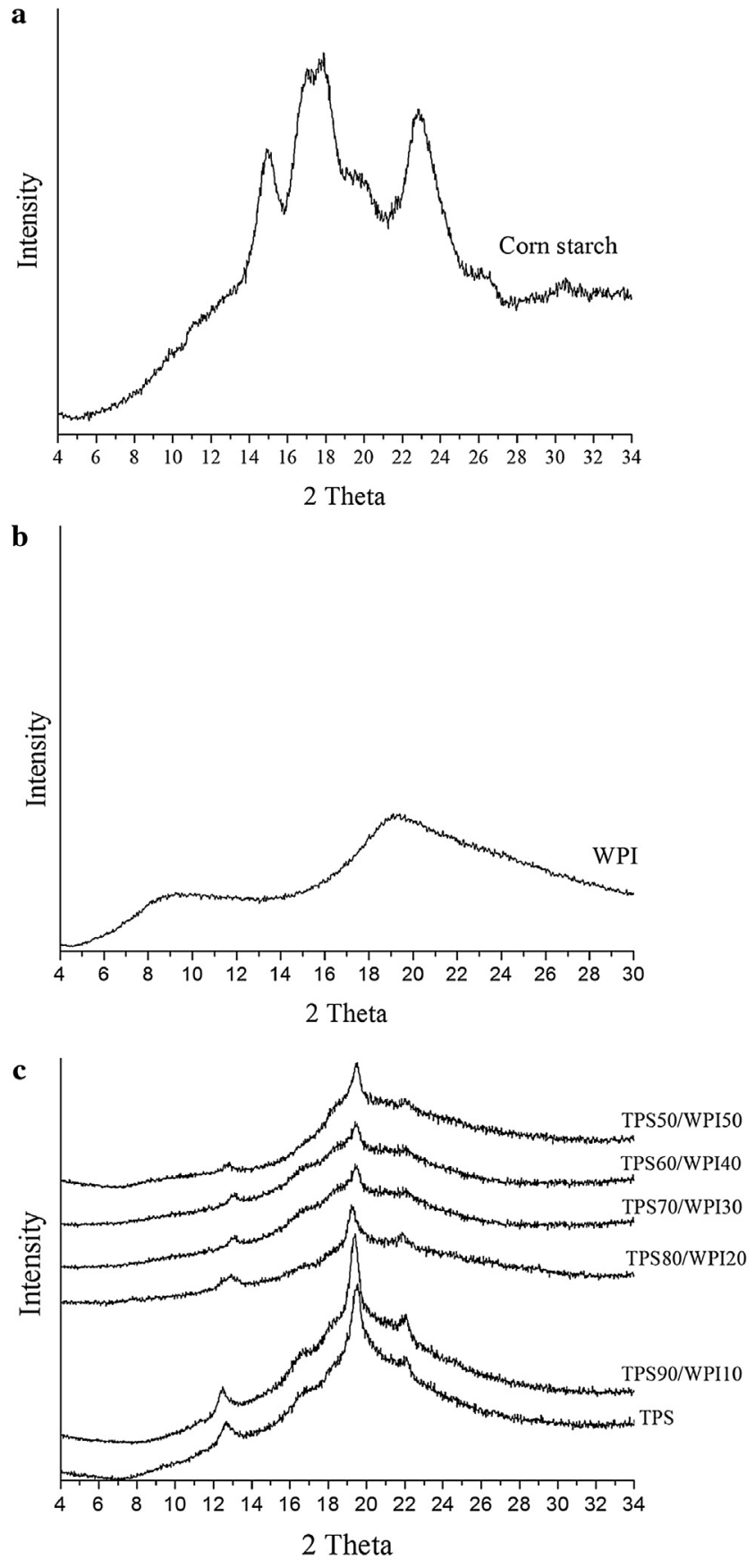

Fig. 1. X-ray diffraction patterns of: a) Powdered corn starch b) powdered WPI; c) corn starch and whey protein isolate films produced by extrusion.

oped in this present study showed no peaks around $2 \theta=16.08^{\circ}$ indicating the absence of amylopectin residual crystallinity.

The diffraction patterns of the TPS/WPI blends are similar to those of the TPS matrix. All films showed peaks around $2 \theta=12.9^{\circ}$

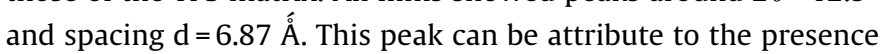
of glycerol complexed with amylose. Furthermore, only the TPS; TPS90/WPI10 and TPS80/WPI20 films showed a diffraction peak at about $2 \theta=22.04^{\circ}$ and spacing $\mathrm{d}=4.04 \AA$ that could also be related to the presence of glycerol. However, it can be seen that with the increase of the WPI concentration and decrease of TPS in TPS70/30; TPS60/40 and TPS50/IPS50 films, the Vh-type crystallinity peaks ( 2 $\theta=19.56^{\circ}$ ) become wider. This fact is the results of the different ratio of starch and whey protein, and the possible decreased for- mation of amylose-glycerol complex. (Mendes et al., 2016). Peaks at $13.7^{\circ}, 19.6^{\circ}$ and $21.1^{\circ}$ are attributed to the Vh-type amylose crystals complexed with lipids and other substances such as glycerol formed during cooling after the process (Carmona, de Campos, Marconcini \& Mattoso, 2014; Mendes et al., 2016; Teixeira et al., 2011), whereas peaks at $16.8^{\circ}, 17.7^{\circ}$ and $29.9^{\circ}$ belong to the Btype crystals that may have been formed during storage due to amylopectin recrystallization (Dang \& Yoksan, 2015). Lavorgna, Piscitelli, Mangiacapra \& Buonocore, (2010) evaluated the effect of the presence of the plasticizer glycerol in chitosan films, finding a diffraction peak around $2 \theta=20^{\circ}$

Fig. 1c shows the absence of A-type crystals, characteristic of cereal starch granules, for all films. This indicates that the native corn starch structure was completely destructured during extrusion (Shi et al., 2007), but some granules might be buried inside (Li et al., 2015) as shows the surface/fractured surface morphology (SEM) of the films, Fig. $2 \mathrm{~h}$.

\subsection{Scanning electron microscopy (SEM)}

X-ray studies are always supplemented by microscopy techniques. Fig. 2(a,b) shows the SEM micrographs of the powdered corn starch and powdered WPI granules. The starch granules (Fig. 2a) had shapes ranging from round to polygonal and their complete disintegration can be observed by the TPS/WPI blend films micrographs (Fig. 2c-h). The WPI particles showed to be spherical with rough and smooth surfaces. The morphology of the protein particles is attributed to the protein composition and their chemical structures. The principal WPI components are $\alpha$-lactalbumin, $\beta$-lactoglobulin and bovine serum albumin (BSA), among others. These proteins are often agglomerated due to hydrophobic intermolecular interactions, disulfide bonds, hydrogen bonds and/or electrostatic interactions depending on the applied conditions, such as temperature, pressure, concentration and $\mathrm{pH}$. Usually, WPI morphology is attributed to the presence of the principal compound, $\beta$-lactoglobulin (Ghosh, Ali, Selvanesan \& Dias, 2010; Havea, Singh \& Creamer, 2001).

The SEM micrographs of the fracture surface of the extruded films are shown in Fig. 2. The TPS film showed a smooth and homogeneous surface (Fig. 2c). This indicates the absence and complete destructuring of native corn starch granules after the extrusion process. This result explains the absence of A-type crystal for TPS film in the XRD graph (Fig. 2c). The TPS90/WPI10 film presented a rough surface and presence of agglomerates (Fig. 2d). The TPS80/WPI20 film showed to be more homogeneous and with few agglomerates (Fig. 2e). The TPS70/WPI30 film (Fig. 2f) presented as homogeneous, however with more evident cracks that might have been formed during the compression molding process. The TPS60/WPI40 and TPS50/WPI50 films (Fig. $2 \mathrm{~g}$ and $2 \mathrm{~h}$ ) showed a homogeneous surface without cracks and with small agglomerated particles. This may indicate a strong interfacial adhesion between the protein and TPS matrix. During the extrusion process, certain surface irregularities may be formed in the structure of the films (Mendes et al., 2016; Tadmor \& Gogos, 2013).

\subsection{Thermogravimetric analysis (TG)}

TG curve and its first derivative (DTG) for corn starch and WPI powdered, and TPS/WPI films are shown in Fig. 3 and were determined to evaluate the films thermal stability. Three degradation stages were observed (Fig. 3). The first stage occurs between 25 and $200{ }^{\circ} \mathrm{C}$ and is not influenced by the mixture of polymers. The mass loss below $200^{\circ} \mathrm{C}$ is attributed to the presence of residual water and low molecular weight volatiles, since the start of protein degradation begins around $225^{\circ} \mathrm{C}$ (Azevedo, Dias, et al., 2015; Ma, Yu \& Ma, 2005; Martínez-Camacho et al., 2010; Sharma \& Luzinov, 

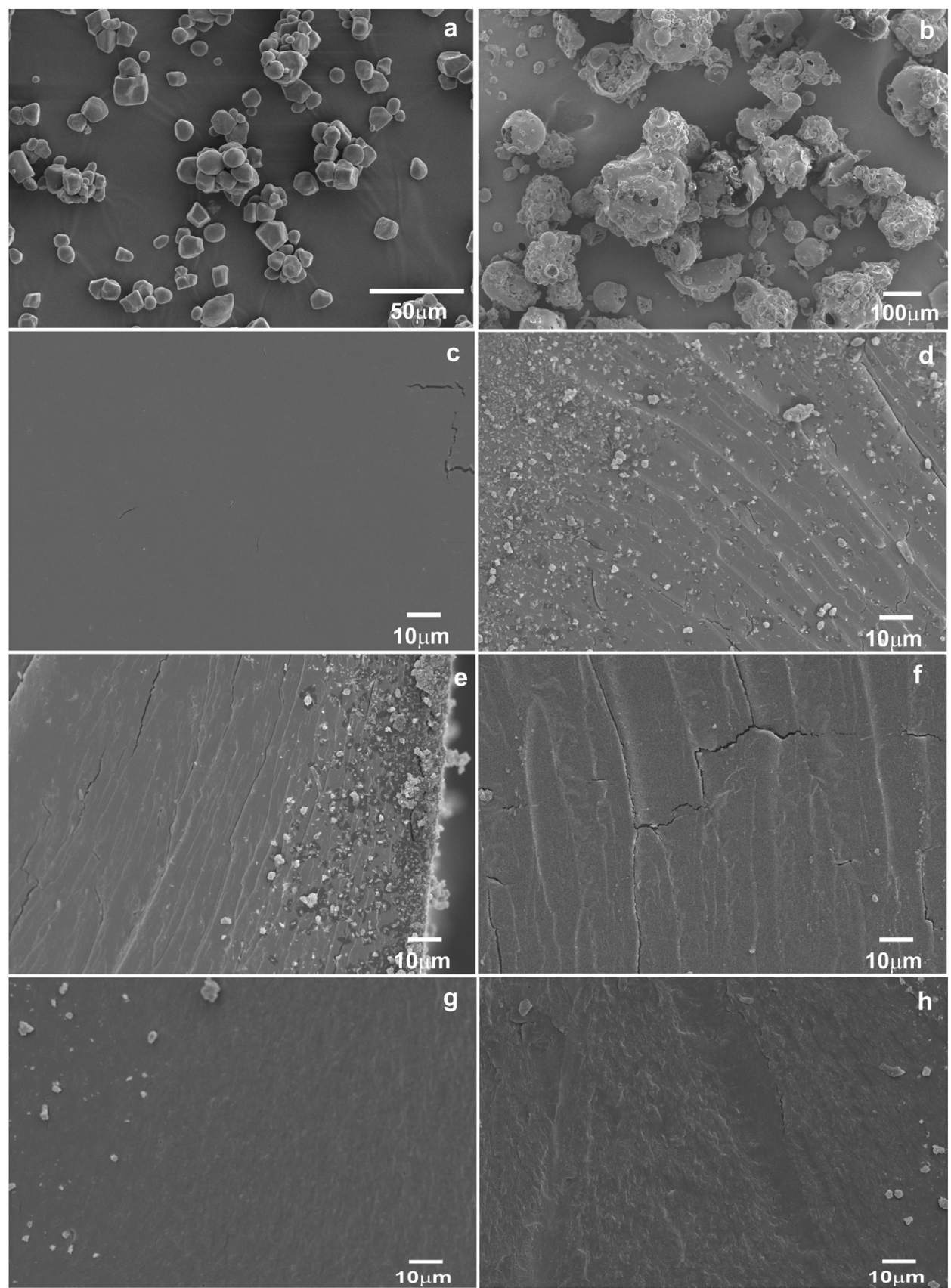

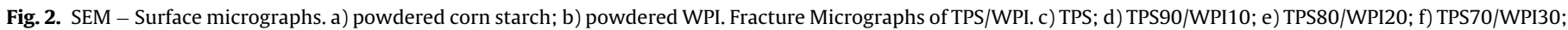
g) TPS60/WPI40; h) TPS50/WPI50.

2013). The second stage was observed from $200^{\circ} \mathrm{C}$ to about $350^{\circ} \mathrm{C}$, corresponding to the thermal decomposition of the components present in the films. The third stage occurs above $350^{\circ} \mathrm{C}$ and corresponds to the oxidative degradation of carbonaceous residues formed during the second stage, in which under air atmosphere, the complete oxidation of the materials occurs (Azevedo, Dias, et al., 2015; Canevarolo Jr, 2004; Pelissari, Grossmann, Yamashita \& Pineda, 2009).

The powdered components (WPI and corn starch) and TPS/WPI films thermal stability parameters are shown in Table 2 . The initial of thermal degradation ( $\mathrm{Ti}$ ) for the TPS decreased compared to powdered corn starch (Table 2). This may be attributable to the extruded material plasticization, which in the presence of water and glycerol decreases the material Ti. Mendes et al. (2016), in research with TPS and chitosan film blends, reported that the addition of chitosan did not significantly alter the thermal stability of mixtures compared to pure TPS. These authors reported an initial degradation temperature for the pure TPS around $277^{\circ} \mathrm{C}$.

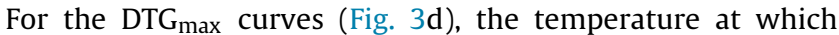
maximum degradation speed occurs, two thermal events are also presented. Table 2 shows an increase of the temperature range for

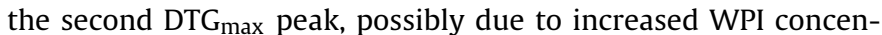
tration. The first peak (between 294.9 and $310.8^{\circ} \mathrm{C}$ ) is attributed to TPS degradation while the second peak (between $463.8^{\circ} \mathrm{C}$ and $543.21^{\circ} \mathrm{C}$ ) is related to WPI degradation according to DTG max temperatures of the WPI and powdered corn starch (Table 2).

When there is substitution of corn starch by WPI, an increase in the film Ti is noteworthy (Table 2), indicating an improvement in the film thermal stability. This can be expected since the mixture of polymers is an alternative in order to improve the performance 

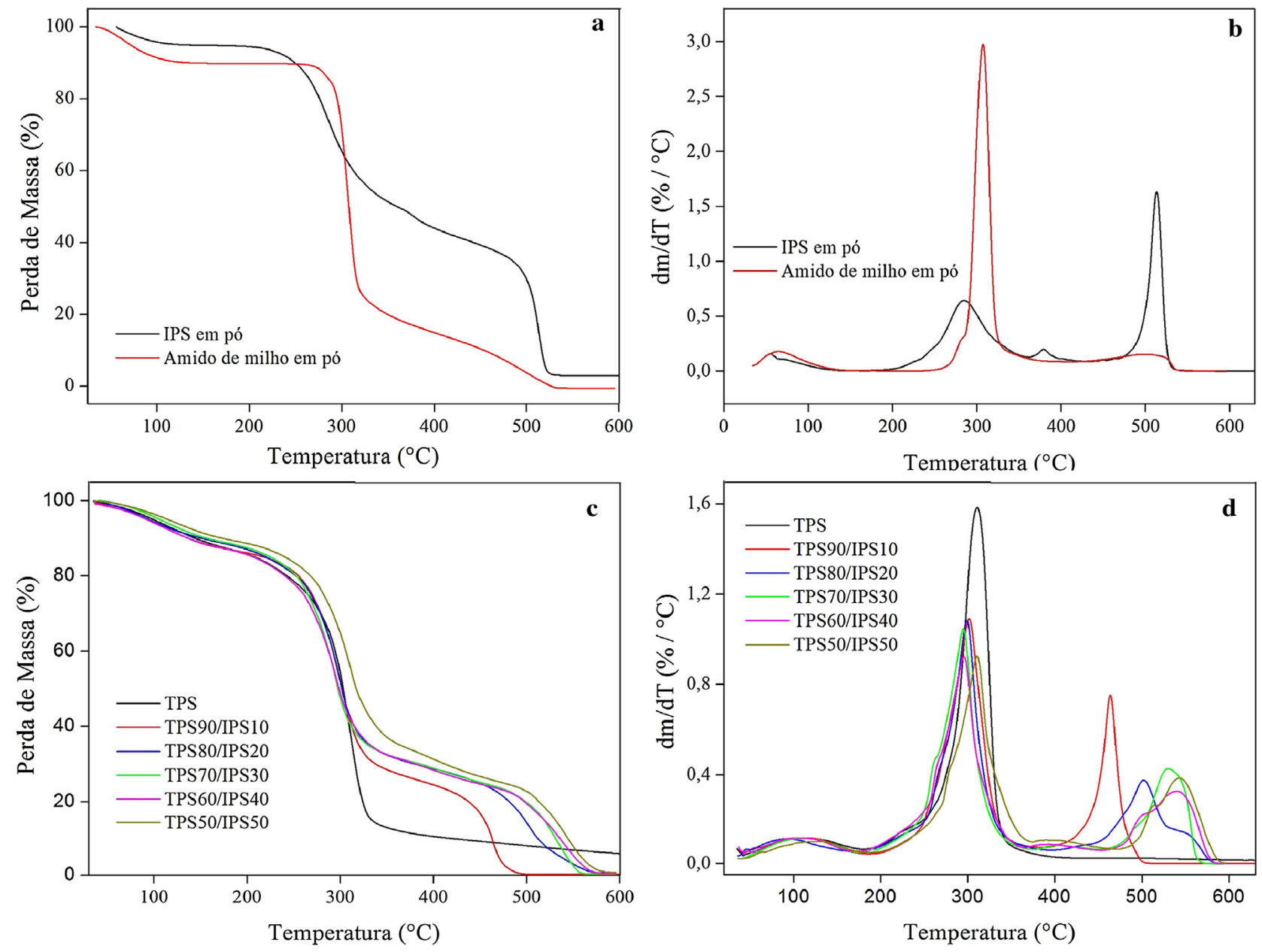

Fig. 3. TGA (a, c) and DTG curves (b, d) of powdered corn starch, powdered WPI and TPS/WPI blend films in synthetic air atmosphere.

Table 2

Thermal stability of corn starch and WPI powder and TPS/WPI blend films obtained by TGA and DSC.

\begin{tabular}{|c|c|c|c|c|c|c|c|}
\hline & $\mathrm{T}_{\mathrm{i}}^{*}\left({ }^{\circ} \mathrm{C}\right)$ & $\mathrm{DTG}_{\max }\left({ }^{\circ} \mathrm{C}\right)$ & $\mathrm{T}_{\mathrm{f}}\left({ }^{\circ} \mathrm{C}\right)$ & $(\%) \operatorname{ML}\left(\mathrm{T}_{\mathrm{i}}-\mathrm{T}_{\mathrm{f}}\right)$ & $\operatorname{Res}_{600{ }^{\circ} \mathrm{C}}(\%)$ & $\mathrm{T}_{\mathrm{m}}\left({ }^{\circ} \mathrm{C}\right)^{\mathrm{a}}$ & $\mathrm{T}_{\mathrm{g}}\left({ }^{\circ} \mathrm{C}\right)$ \\
\hline Corn starch powder & 285.2 & 307.3 & 541.9 & 84.6 & 0.12 & 109.7 & -28.9 \\
\hline WPI powder & $250.6 / 401.2$ & $285.1 / 512.8$ & $360.7 / 540.6$ & 89.7 & 1.8 & - & 186.1 \\
\hline TPS & 230.1 & 309.2 & 369.7 & 84.2 & 3.2 & 144.5 & 56.9 \\
\hline TPS90/WPI10 & $229.2 / 395.6$ & $301.8 / 463.7$ & $365.1 / 505.7$ & 81.7 & 0.3 & 189.2 & 102.6 \\
\hline TPS80/WPI20 & $232.7 / 431.9$ & $298.9 / 502.1$ & $366.5 / 587.7$ & 82.7 & 0.6 & 189.1 & 104.1 \\
\hline TPS70/WPI30 & $234.53 / 459.72$ & $294.9 / 530.4$ & $371.3 / 573.1$ & 83.2 & 0.4 & 189.4 & 106.7 \\
\hline TPS60/WPI40 & $248.8 / 462.8$ & $295.7 / 539.8$ & $365.1 / 586.9$ & 81.5 & 0.5 & 188.7 & 101.5 \\
\hline TPS50/WPI50 & $252.5 / 475.8$ & $310.8 / 543.2$ & $372.7 / 585.3$ & 83.7 & 0.8 & 189.1 & 102.1 \\
\hline
\end{tabular}

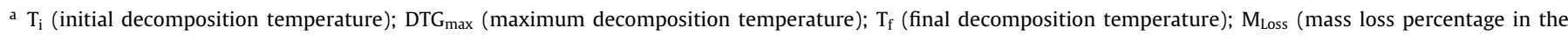
decomposition range); $\operatorname{Res}_{600}{ }^{\circ} \mathrm{C}$ (percentage of residue at $600{ }^{\circ} \mathrm{C}$ ); $\mathrm{T}_{\mathrm{m}}$ (crystalline melting temperature); $\mathrm{T}_{\mathrm{g}}$ (glass transition temperature).

properties in films. Moreover, with the addition of WPI to the TPS matrix, it can be noted that the second thermal decomposition stage takes place in two stages (two temperature peaks), unlike for the TPS film, probably due to the presence of other components present in WPI which interferes with the degradation mechanism. However, the substitution of corn starch by WPI did not alter the film degradation profile compared to the first $\mathrm{T}_{\mathrm{f}}$ peak $\left(365.1^{\circ} \mathrm{C}\right.$ to $372.7^{\circ} \mathrm{C}$ ) compared to the TPS film. Nevertheless, there is a $T_{f}$ increase in the second temperature peak $\left(505.7^{\circ} \mathrm{C}\right.$ to $\left.587.7^{\circ} \mathrm{C}\right)$ indicating that the presence of WPI is responsible for increasing the thermal stability of the blends. Teixeira et al. (2011) reported on work conducted on TPS and cellulose nanofiber that thermal degradation of the TPS is between $300^{\circ} \mathrm{C}$ and $350^{\circ} \mathrm{C}$. Mariani, Allganer, Oliveira, Cardoso \& Innocentini-Mei, (2009) studied the effect of increasing concentrations of soy protein isolate (SPI) on corn starch and polycaprolactone (PCL) blends processed by extrusion. These authors reported that the corn starch and SPI addition was responsible for the reduction of the thermal properties of the materials compared to pure PCL. However, with the increased amount of SPI and reduced starch incorporated in the sample, the thermal properties tended to increase.

With the increasing concentration of WPI in the blends, there is a reduction in the mass loss (\%ML) percentage compared to the corn starch and the powdered WPI. This indicates that the TPS/WPI blends became more stable to thermal decomposition. Authors report that material stability to thermal decomposition is related to a decrease in the mass loss $(\% \mathrm{ML})$ percentage range (Azevedo, Dias, et al. 2015; Canevarolo Jr, 2004). 
Table 3

Tensility properties $\left(\sigma_{\max }, \mathrm{EM}, \epsilon\right)$; puncture (PS and PD) of TPS/WPI films.

\begin{tabular}{|c|c|c|c|c|c|}
\hline Film & $\begin{array}{l}\text { Tensile } \\
\text { strength }\left(\sigma_{\max }\right) \\
(\mathrm{MPa})\end{array}$ & $\begin{array}{l}\text { Elastic } \\
\text { Modulus (EM) } \\
(\mathrm{MPa})\end{array}$ & $\begin{array}{l}\text { Elongation at } \\
\text { break }(\epsilon)(\%)\end{array}$ & $\begin{array}{l}\text { Puncture } \\
\text { strength/thickness } \\
(\mathrm{PS})(\mathrm{N} / \mathrm{mm})\end{array}$ & $\begin{array}{l}\text { Puncture } \\
\text { Deformation } \\
\text { (PD) }(\mathrm{mm})\end{array}$ \\
\hline TPS & $3.85 \pm 0.62 \mathrm{a}$ & $143.71 \pm 4.6 \mathrm{a}$ & $32.76 \pm 3.2 \mathrm{a}$ & $92.40 \pm 5.3 \mathrm{a}$ & $4.96 \pm 0.36 \mathrm{a}$ \\
\hline TPS90/WPI10 & $4.04 \pm 0.07 \mathrm{a}$ & $151.40 \pm 22.8 \mathrm{a}$ & $21.60 \pm 1.5 b$ & $70.50 \pm 9.7 b$ & $3.67 \pm 0.18 b$ \\
\hline TPS80/WPI20 & $3.84 \pm 0.38 \mathrm{a}$ & $152.53 \pm 11.9 \mathrm{a}$ & $11.70 \pm 3.4 \mathrm{c}$ & $56.74 \pm 3.3 \mathrm{c}$ & $3.01 \pm 0.27 c$ \\
\hline TPS70/WPI30 & $5.73 \pm 0.38 b$ & $198.90 \pm 11.0 \mathrm{~b}$ & $10.65 \pm 1.3 c$ & $75.40 \pm 5.8 b$ & $3.38 \pm 0.32 \mathrm{~d}$ \\
\hline TPS60/WPI40 & $4.24 \pm 0.34 \mathrm{a}$ & $230.35 \pm 22.1 b$ & $2.83 \pm 1.1 \mathrm{~d}$ & $19.57 \pm 9.6 \mathrm{~d}$ & $1.78 \pm 0.18 \mathrm{e}$ \\
\hline TPS50/WPI50 & $3.07 \pm 0.49 \mathrm{a}$ & $150.74 \pm 16.7 \mathrm{a}$ & $3.84 \pm 1.3 \mathrm{~d}$ & $11.45 \pm 3.1 \mathrm{~d}$ & $1.86 \pm 0.45 \mathrm{e}$ \\
\hline
\end{tabular}

Means observed in the column with the same letter are not statistically different $(p<0.05)$.

In studies with WPI and whey protein concentrate blends at different concentrations of glycerol, Ramos et al. (2012), obtained high mass loss at temperatures between $280^{\circ} \mathrm{C}$ and $500^{\circ} \mathrm{C}$. These authors reported that this loss is associated with protein degradation and with the glycerol plasticizer, incorporated in the film matrix. Table 2 shows the absence of residual substances $\left(\operatorname{Res}_{600}{ }^{\circ} \mathrm{C}\right)$ after burning the films, since there is complete oxidation of the material under air atmosphere. Thus, the TPS/WPI blends showed increased thermal stability compared to the TPS film.

\subsection{Differential scanning calorimetry (DSC)}

The DSC analysis was performed for a better understanding of the interactions between TPS and WPI and transition temperatures. All films showed matrix crystalline phase melting temperature $\left(\mathrm{T}_{\mathrm{m}}\right)$ (Table 2). The occurrence of a single crystalline melting temperature is related to homogeneity and miscibility among the film components (Lopez, Garcia, Villar, Gentili, Rodriguez \& Albertengo, 2014).

$\mathrm{T}_{\mathrm{m}}$ increased with the WPI addition compared to the TPS film (Table 2). This increase can be attributed to the interaction between starch molecules and proteins due to intermolecular forces with stronger bonds. Lopez, Garcia, Villar, Gentili, Rodriguez \& Albertengo, (2014) reported that in the crystalline regions of the TPS matrix, the interactions among polymer chains are strong because of their chemical compatibility. These authors reported $\mathrm{T}_{\mathrm{m}}=155^{\circ} \mathrm{C}$ for TPS films and $\mathrm{T}_{\mathrm{m}}$ from $147.2^{\circ} \mathrm{C}$ to $154.8^{\circ} \mathrm{C}$ in TPS/chitosan blends. Sharma and Luzinov, (2013) reported the absence of crystallinity for WPI due to whey protein globule denaturation, indicating a plasticization effect of water. These authors suggest that water molecules were linked to proteic macromolecules via hydrogen bonds. This information was corroborated by the absence of crystallinity in the X-ray diffractograms of this study for WPI.

It was observed that the TPS film $\mathrm{T}_{\mathrm{g}}$ was $56.9^{\circ} \mathrm{C}$ (Table 2). The addition WPI in the TPS matrix increased the $T_{g}$, thereby decreasing the mobility of the polymer chains. This indicates an increase in thermal stability of the films. Sharma and Luzinov, (2013) found a $T_{g}=120^{\circ} \mathrm{C}$ for in films with WPI and albumin blends. Azevedo, Dias. et al. (2015) reported $T_{g}=143.46$ value for pure WPI films. Hernandez-Izquierdo, Reid, McHugh, Berrios \& Krochta, (2008) have reported the existence of an endothermic peak at $148.3^{\circ} \mathrm{C}$ for pure WPI films obtained by extrusion. $\mathrm{T}_{\mathrm{g}}$ values for powdered WPI were reported by Zhou and Labuza (2007), who found $153^{\circ} \mathrm{C}$ and Adhikari, Howes, Bhandari \& Langrish, (2009) who observed values from around $75-119{ }^{\circ} \mathrm{C}$ containing 7 to $16 \%$ water. The $\mathrm{T}_{\mathrm{g}}$ value for polyvinyl and corn starch film blends (WVP/starch 1:1) was higher $\left(\mathrm{T}_{\mathrm{g}} 76.1^{\circ} \mathrm{C}\right)$ when compared to pure WVP polymer $\left(\mathrm{T}_{\mathrm{g}} 70.5^{\circ} \mathrm{C}\right)$. This increase is attributed to the presence of hydrogen bond interactions between starch and WVP (Aydin \& Ilberg, 2016).

\subsection{Mechanical properties}

The effect of replacing corn starch by WPI was significant $(\mathrm{p}<0.05)$ for tensile strength $\left(\sigma_{\max }\right)$, elastic modulus $(E M)$, elongation $(\epsilon)$, puncture strength (PS), puncture deformation (PD) and are shown in Table 3. For $\sigma_{\max }$, there was a significant difference only for the TPS70/WPI30 film with an increase of $48.8 \%$ compared to the TPS film (Table 3). This indicates that a higher force was needed to break the film. For films with concentrations above 30\% WPI, the $\sigma_{\max }$ value was reduced. We observed an increase in the EM (60.3\%) with up to $40 \%$ WPI for TPS/WPI film blends. This indicates less movement of the polymer chains, characterizing the films them as being highly rigid, i.e., less flexible. However, TPS70/30WPI and TPS60/WPI40 films showed no significant difference between each other (Table 3 ). The high rigidity can be attributed to a reduction of film plasticization during the extrusion process at high temperatures due to possible water and glycerol evaporation. The water also has a plasticizing effect on hydrophilic films, but in the presence of low humidity, the film becomes brittle due to reduced residual water in the film (Coupland, Shaw, Monahan, O'Riordan \& O'Sullivan, 2000).

With the EM increase, there was an $88.3 \%$ reduction of the elongation $(\varepsilon)$ for all films compared to the TPS film, indicating decreased plasticizer effect and less film stretching. In general, protein-based films have low tensile strength, i.e., high modulus of elasticity and low extensibility (Sharma \& Luzinov, 2013). Yan, Hou, Guo \& Dong, (2012) investigated the effects of extrusion for film formation and the glycerol concentration on the properties of starch films. With increasing glycerol content, the film becomes more flexible with a greater elongation at break and lower tensile strength. Plasticizers alter the film flexibility and extensibility, with a subsequent modulus of elasticity and tensile strength decrease due to the reduction of hydrogen bonds among polymer chains, (Alves, Mali, Beléia \& Grossmann, 2007; Mali \& Grossmann, 2003). The addition of plasticizers, providing flexibility, becomes necessary due to the fragility of WPI-based films (Shaw, Monahan, O'riordan \& O'sullivan, 2002). Previous research has reported that for obtaining plastic with an acceptable performance, from protein, the use of plasticizers such as water or others with low molecular weight molecules is necessary to increase the protein processability and thermoplasticity/polymerization during molding (Matveev, Grinberg \& Tolstoguzov, 2000; Rouilly, Orliac, Silvestre, \& Rigal, 2001).

In addition to interfering with the WPI-based films properties, the absence of plasticizers also affects the development of starch films. According to Liu and Han (2005), the absence of plasticizers would form a film with a biphasic structure composed of amylose and amylopectin. The presence of plasticizers in starch films assists in the disruption of the double helix of amylose with amylopectin fragments formation, thus reducing the amylose/amylopectin interaction, forming a flexible film.

For the puncture test, WPI addition decreased the film PS and PD by $87.6 \%$ and $62.5 \%$ respectively (Table 3 ). This indicates less poly- 
Table 4

Effect of corn starch substitution on WVP and color parameters (a*, $\mathrm{b}^{*}$, hue, and chroma) of TPS/WPI films.

\begin{tabular}{|c|c|c|c|c|c|c|}
\hline Films & $\begin{array}{l}\text { WVP x } 10^{-12} \\
\left(\mathrm{~g} \mathrm{~m}^{-} 1 \mathrm{~s}^{-1} \mathrm{~Pa}\right)\end{array}$ & $\begin{array}{l}\text { Transparency } \\
(\log (\% \mathrm{~T}) / \mathrm{mm})\end{array}$ & $a^{*}$ & $b^{*}$ & chroma & hue \\
\hline TPS & $4.63 \pm 0.32 \mathrm{a}$ & $5.39 \pm 0.11 \mathrm{a}$ & $-0.76 \pm 0.12 \mathrm{a}$ & $4.07 \pm 0.32 \mathrm{a}$ & $3.48 \pm 1.15 \mathrm{a}$ & $-77.76 \pm 0.29 a$ \\
\hline TPS90/WPI10 & $3.83 \pm 0.07 b$ & $4.41 \pm 0.04 \mathrm{~b}$ & $-0.91 \pm 0.07 \mathrm{a}$ & $4.13 \pm 0.45 \mathrm{a}$ & $4.17 \pm 0.32 \mathrm{a}$ & $-77.56 \pm 0.40 \mathrm{a}$ \\
\hline TPS80/WPI20 & $3.09 \pm 0.15 c$ & $4.43 \pm 0.10 b$ & $-0.88 \pm 0.30 \mathrm{a}$ & $3.40 \pm 1.10 \mathrm{a}$ & $4.23 \pm 0.48 \mathrm{a}$ & $-77.64 \pm 0.93 a$ \\
\hline TPS70/WPI30 & $2.71 \pm 0.26 c$ & $4.99 \pm 0.10 c$ & $-0.50 \pm 0.08 b$ & $5.08 \pm 0.52 b$ & $5.10 \pm 0.52 b$ & $-84.41 \pm 0.45 b$ \\
\hline TPS60/WPI40 & $2.84 \pm 0.28 c$ & $4.62 \pm 0.14 \mathrm{~d}$ & $-1.25 \pm 0.19 c$ & $6.76 \pm 0.93 c$ & $6.89 \pm 0.84 c$ & $-79.50 \pm 0.27 c$ \\
\hline TPS50/WPI50 & $2.45 \pm 0.34 c$ & $3.91 \pm 0.05 \mathrm{e}$ & $-1.47 \pm 0.11 \mathrm{~d}$ & $11.93 \pm 1.36 \mathrm{~d}$ & $12.02 \pm 1.38 \mathrm{~d}$ & $-82.93 \pm 0.30 \mathrm{~d}$ \\
\hline
\end{tabular}

Means observed in the column with the same letter are not statistically different $(p<0.05)$.

mer chain mobility, less film deformation and perforation strength and, consequently, films that are weaker and more fragile.

\subsection{Water vapor permeability (WVP)}

The corn starch substitution by WPI was significant $(\mathrm{p}<0.05)$ for WVP (Table 4). In barrier properties studies, thickness control becomes a very important variable because with increased thickness, WVP decreases (McHugh \& John, 1994). In this work, the thickness of the films showed no significant difference $(\mathrm{p}<0.05)$ and ranged from 330 to $390 \mu \mathrm{m}$.

According to Table 4, the TPS film had the highest WVP. This increase can be attributed to the high affinity of glycerol for starch which promotes the diffusion of these molecules. Because it is a hydrophilic molecule, glycerol can easily lodge between the starch molecules and form hydrogen bonds with amylose and amylopectin hydroxyl groups (Laohakunjit \& Noomhorm, 2004). Yan, Hou, Guo \& Dong, (2012) reported that the extrusion process can also cause a certain degree of depolymerization and hydrogen bond breakage in starch, with consequent water absorption facility.

The WVP of TPS/WPI blend films decreased with increasing substitution of corn starch by WPI (Table 4). However, the film did not differ significantly above $20 \%$ corn starch replacement by WPI. WPI is a hydrophilic polymer which has hydroxyl groups, thus, the water could easily permeate the film (Wang, Zhang, Han \& Bai, 2009). However, possibly due to the crystalline phase formed in the polymer matrix, as shown by the X-ray diffraction, the water vapor passage becomes limited. The water vapor and gas permeation occurs in the polymer amorphous regions in empty spaces while in the crystalline phase, a reduction in the water vapor passage occurs (Sarantópoulos et al., 2002). Moreover, WVP is related to factors such as film structure, amount of hydrophilic/hydrophobic material, polymer chain mobility due to the presence of plasticizers and the ratio between amorphous and crystalline regions (Garcia, Martino \& Zaritzky, 2000). Another factor responsible for the WVP reduction may be associated with protein denaturation above $50^{\circ} \mathrm{C}$. Since the whey protein denatures, it become insoluble and aggregated (Onwulata, Konstance, Cooke \& Farrell, 2003). Changes in the globular structure of proteins occur above 50 and $80^{\circ} \mathrm{C}$ for $\alpha$-lactalbumin and $\beta$-lactoglobulin, respectively (Hong $\&$ Creamer, 2002).

Apart from possible crystallinity formed in the TPS matrix and formation of insoluble WPI aggregates, as shown in the Xray diffraction, resistance to water vapor of the TPS/WPI blends increased, possibly due to the presence of citric acid in the film formulation. Azevedo, Silva, Pereira, da Costa \& Borges (2015) studied the effect of citric acid on the physical properties of WPI film and reported a decrease in WVP with the addition of $5 \%$ citric acid. These authors reported that in the presence of citric acid, the hydrogen bond formed with a hydroxyl group and a carboxyl group enhances the inter/intramolecular interaction among additives present in the film. This result corroborates with the SEM micrographs, which indicated a strong interfacial adhesion between the protein and TPS matrix. Lopez, Zaritzky, Grossmann \& García, (2013) reported a
$62 \%$ reduction of WVP in thermoplastic corn starch with acetylated starch and glycerol blends. These authors attributed this result to the hydrophobic character of the acetylated starch.

\subsection{Optical properties}

Color attributes are important because they are directly related to consumer acceptance. The optical transparency properties, $\mathrm{a}^{*}, \mathrm{~b}^{*}$, hue and chroma presented significant difference $(\mathrm{p}<0.05)$ among the films with substitution of corn starch by whey protein isolate (Table 4$)$. The luminosity $\left(\mathrm{L}^{*}\right)$, which ranges from zero (black) to 100 (white), did not present significant difference $(\mathrm{p}<0.05)$ among treatments, ranging from 85.17 to 88.75 , indicating lighter films approaching the color white.

The films presented significant differences $(p<0.05)$ with a transparency reduction compared to the TPS film (Table 4). Transparency is related to the film internal structure (Sanchez-Gonzalez, Chafer, Chiralt \& Gonzalez-Martinez, 2010a). The film crystallinity, as shown by X-ray diffraction, possibly decreased light transmission through the film thereby reducing the transparency. Brindle and Krochta (2008), reported that WPI films with glycerol were transparent whereas WPI/hydroxypropylmethylcellulose (HPMC) blends and glycerol became translucent, indicating some degree of immiscibility between WPI and HPMC.

The $\left(-\mathrm{a}^{*}\right)$ parameter, that corresponds to a tendency towards green, showed significant difference $(\mathrm{p}<0.05)$ and increased with WPI addition only for the TPS60/WPI40 and TPS50/WPI50 films. The hue, chroma and $b^{*}$ parameters had a significant effect $(\mathrm{p}<0.05)$ with the substitution of starch by whey protein isolate. The $\left(+b^{*}\right)$ parameter, related to yellow color, increased with WPI addition in the TPS70/WPI30; TPS60/WPI40 and TPS50/WPI50 films. Chroma is a measure of color saturation (Zhong, Song \& Li, 2011). An increase in chroma values was observed, characterizing films with high color intensity. The Hue parameter is a value in degrees and refers to the color tone in the three-dimensional color diagram: chroma $+\mathrm{a}^{*}$ $0^{\circ}$ (red), $+b^{*} 90^{\circ}$ (yellow), $-a^{*} 180^{\circ}$ (green) and $-b^{*} 270^{\circ}$ (blue). Although yellow and red are two totally different tonalities, mixing yellow with red results in orange color (yellow-red), mixing yellow and green results in yellow-green, blue mixed with green results in blue-green and so on (Sensing, 2007).

There was a hue increase only for TPS70/WPI30; TPS60/WPI40 and TPS50/WPI50 films. Thus, the position of the TPS/WPI film blends can be estimate in a greenish-yellow tonality within Cielab color solid. Silva, Pereira, Carvalho \& Ferrua, (2007) reported that the film color can be influenced by the starch source. Cassava starch films presented higher color difference when compared to corn and potato starch films. During the starch gelatinization process, changes in the coloration occur due to the loss of structure and crystallinity of the starch granules, the gel thus becoming a structure with a certain opacity (Guerrero, Beatty, Kerry \& De La Caba, 2012). Films based on thermoplastic corn starch (TPS) and chitosan/chitin were obtained by thermo-compression and showed a yellowish color. These authors reported that the processing temperature promoted chemical reactions such as the Maillard reaction related to 
non-enzymatic browning (Lopez, Garcia, Villar, Gentili, Rodriguez \& Albertengo, 2014).

\section{Conclusion}

Based on the X-Ray diffractograms and scanning electron microscopy, native starch granules were completely unstructured during extrusion, resulting in homogeneous films and strong adhesion between the TPS matrix and whey proteins. All films presented reduced WVP, not being significant at concentrations above $20 \%$ WPI compared to the TPS film. The TPS70/WPI30 film presented as more resistant, less flexible and with low elongation compared to the TPS film. The addition of WPI in the TPS matrix made the films more stable to thermal decomposition and caused alterations in the optical properties, with a greenish-yellow tonality and reduction of transparency compared to the TPS film. Thus, extrusion of biodegradable polymer blends is an important step for the development of films for use in packaging, the TPS70/WPI30 being the best film for continued future work.

\section{Acknowledgments}

The authors thank CNPq (National Council for Scientific and Technological Development), FAPEMIG (Research Support Foundation of the State of Minas Gerais) for financial support. SISNANO (National System for Laboratory in Nanotechnology) and LNNA (National Nanotechnology Laboratory for Agrobusiness, Embrapa Instrumentação), Hilmar Ingredients, for the whey protein isolate donation.

\section{References}

Šimkovic, I. (2013). Unexplored possibilities of all-polysaccharide composites. Carbohydrate Polymers, 95(2), 697-715.

ASTM. (2000a). Standard practice for conditioning plastics for testing, D618-00. Philadephia, PA: ASTM [p. 4]

ASTM. (2000b). Standard test method for water vapor transmission of materials E96-00. Philadelphia, PA: ASTM [p. 9].

ASTM. (2002). Standard test method for tensile properties of thin plastic sheeting D882-02. Philadelphia, PA: ASTM [p. 10].

ASTM. (2003a). Standard test method for transition temperatures of polymers by differential scanning calorimetry D3418-03. Philadelphia, PA: ASTM [p. 7]

ASTM. (2003b). Standard test method for transparency of plastic sheeting D1746-03. Philadelphia, PA: ASTM.

Adhikari, B., Howes, T., Bhandari, B., \& Langrish, T. (2009). Effect of addition of proteins on the production of amorphous sucrose powder through spray drying. Journal of Food Engineering, 94(2), 144-153.

Alves, V. D., Mali, S., Beléia, A., \& Grossmann, M. V. E. (2007). Effect of glycerol and amylose enrichment on cassava starch film properties. Journal of Food Engineering, 78(3), 941-946.

Angellier, H., Molina-Boisseau, S., Dole, P., \& Dufresne, A. (2006). Thermoplastic starch-waxy maize starch nanocrystals nanocomposites. Biomacromolecules, $7(2), 531-539$

Averous, L., \& Boquillon, N. (2004). Biocomposites based on plasticized starch: Thermal and mechanical behaviours. Carbohydrate Polymers, 56(2), 111-122.

Aydın, A. A., \& Ilberg, V. (2016). Effect of different polyol-based plasticizers on thermal properties of polyvinyl alcohol: Starch blends. Carbohydrate Polymers $136,441-448$.

Azevedo, V. M., Dias, M. V., Borges, S. V., Costa, A. L. R., Silva, E. K., Medeiros, A. A. et al. (2015). Development of whey protein isolate bio-nanocomposites: Effect of montmorillonite and citric acid on structural, thermal, morphological and mechanical properties. Food Hydrocolloids, 48, 179-188.

Azevedo, V. M., Silva, E. K., Pereira, C. F. G., da Costa, J. M. G., \& Borges, S. V. (2015). Whey protein isolate biodegradable films: Influence of the citric acid and montmorillonite clay nanoparticles on the physical properties. Food Hydrocolloids, 43, 252-258.

Bastos, D. C., Santos, A. E., da Silva, M. L., \& Simão, R. A. (2009). Hydrophobic corn starch thermoplastic films produced by plasma treatment. Ultramicroscopy, 109(8), 1089-1093

Bertuzzi, M., Vidaurre, E. C., Armada, M., \& Gottifredi, J. (2007). Water vapor permeability of edible starch based films. Journal of Food Engineering, 80(3), 972-978

Brindle, L., \& Krochta, J. (2008). Physical properties of whey protein-hydroxypropylmethylcellulose blend edible films. Journal of Food Science, 73(9), E446-E454.

Canevarolo, S. V., Jr. (2004). Técnicas de caracterização de polímeros.
Carmona, V. B., de Campos, A., Marconcini, J. M., \& Mattoso, L. H. C. (2014). Kinetics of thermal degradation applied to biocomposites with TPS, PCL and sisal fibers by non-isothermal procedures. Journal of Thermal Analysis and Calorimetry, 115(1), 153-160.

Chen, C. H., \& Lai, L. S. (2008). Mechanical and water vapor barrier properties of tapioca starch/decolorized hsian-tsao leaf gum films in the presence of plasticizer. Food Hydrocolloids, 22(8), 1584-1595.

Chen, X., Zhang, Y., Zhang, P., Fan, B., \& Wu, Q. (2012). Thermoplastic starch modified with polyurethane microparticles: Effects of hydrophilicity of polyurethane prepolymer. Starch-Stärke, 64(4), 255-262.

Cheng, M., Deng, J., Yang, F., Gong, Y., Zhao, N., \& Zhang, X. (2003). Study on physical properties and nerve cell affinity of composite films from chitosan and gelatin solutions. Biomaterials, 24(17), 2871-2880.

Coupland, J. N., Shaw, N. B., Monahan, F. J., O'Riordan, E. D., \& O'Sullivan, M. (2000). Modeling the effect of glycerol on the moisture sorption behavior of whey protein edible films. Journal of Food Engineering, 43(1), 25-30.

Curvelo, A., De Carvalho, A., \& Agnelli, J. (2001). Thermoplastic starch-cellulosic fibers composites: Preliminary results. Carbohydrate Polymers, 45(2), 183-188.

Dang, K. M., \& Yoksan, R. (2015). Development of thermoplastic starch blown film by incorporating plasticized chitosan. Carbohydrate Polymers, 115, 575-581.

Fajardo, P., Martins, J., Fuciños, C., Pastrana, L., Teixeira, J., \& Vicente, A. (2010). Evaluation of a chitosan-based edible film as carrier of natamycin to improve the storability of Saloio cheese. Journal of Food Engineering, 101(4), 349-356.

Ferreira, C. O., Nunes, C. A., Delgadillo, I., \& Lopes-da-Silva, J. (2009). Characterization of chitosan-whey protein films at acid pH. Food Research International, 42(7), 807-813.

Forssell, P., Lahtinen, R., Lahelin, M., \& Myllärinen, P. (2002). Oxygen permeability of amylose and amylopectin films. Carbohydrate Polymers, 47(2), 125-129.

García, L., Cova, A., Sandoval, A. J., Müller, A. J., \& Carrasquel, L. M. (2012). Glass transition temperatures of cassava starch-whey protein concentrate systems at low and intermediate water content. Carbohydrate Polymers, 87(2), 1375-1382.

Garcia, M., Martino, M., \& Zaritzky, N. (2000). Lipid addition to improve barrier properties of edible starch-based films and coatings. Journal of Food Science, 65(6), 941-944

Ghosh, A., Ali, M. A., Selvanesan, L., \& Dias, G. J. (2010). Structure-function characteristics of the biomaterials based on milk-derived proteins. International Journal of Biological Macromolecules, 46(4), 404-411.

Gross, R. A., \& Kalra, B. (2002). Biodegradable polymers for the environment. Science, 297(5582), 803-807.

Guerrero, P., Beatty, E., Kerry, J., \& De La Caba, K. (2012). Extrusion of soy protein with gelatin and sugars at low moisture content. Journal of Food Engineering, 110(1), 53-59,

Haider, S., Park, S.-Y., \& Lee, S.-H. (2008). Preparation, swelling and electro-mechano-chemical behaviors of a gelatin-chitosan blend membrane. Soft Matter, 4(3), 485-492.

Havea, P., Singh, H., \& Creamer, L. K. (2001). Characterization of heat-induced aggregates of $\beta$-lactoglobulin, $\alpha$-lactalbumin and bovine serum albumin in a whey protein concentrate environment. Journal of Dairy Research, 68(03), 483-497.

Hernandez-Izquierdo, V., Reid, D., McHugh, T., Berrios, D. J., \& Krochta, J. (2008). Thermal transitions and extrusion of glycerol-Plasticized whey protein mixtures. Journal of Food Science, 73(4), E169-E175.

Herrera Brandelero, R. P., VICTORIA EIRAS VICTORIA EIRAS GROSSMANN, M., \& Yamashita, F. (2011). Effect of the method of production of the blends on mechanical and structural properties of biodegradable starch films produced by blown extrusion. Carbohydrate Polymers, 86(3), 1344-1350.

Hong, Y.-H., \& Creamer, L. K. (2002). Changed protein structures of bovine $\beta$-lactoglobulin B and $\alpha$-lactalbumin as a consequence of heat treatment. International Dairy Journal, 12(4), 345-359.

Hong, S. I., \& Krochta, J. (2003). Oxygen barrier properties of whey protein isolate coatings on polypropylene films. Journal of Food Science, 68(1), 224-228.

Kim, H.-Y., Han, J.-A., Kweon, D.-K., Park, J.-D., \& Lim, S.-T. (2013). Effect of ultrasonic treatments on nanoparticle preparation of acid-hydrolyzed waxy maize starch. Carbohydrate Polymers, 93(2), 582-588.

López, O. V., Zaritzky, N. E., Grossmann, M. V., \& García, M. A. (2013). Acetylated and native corn starch blend films produced by blown extrusion. Journal of Food Engineering, 116(2), 286-297.

Laohakunjit, N., \& Noomhorm, A. (2004). Effect of plasticizers on mechanical and barrier properties of rice starch film. Starch-Stärke, 56(8), 348-356.

Lavorgna, M., Piscitelli, F., Mangiacapra, P., \& Buonocore, G. G. (2010). Study of the combined effect of both clay and glycerol plasticizer on the properties of chitosan films. Carbohydrate Polymers, 82(2), 291-298.

Leuangsukrerk, M., Phupoksakul, T., Tananuwong, K., Borompichaichartkul, C., \& Janjarasskul, T. (2014). Properties of konjac glucomannan-whey protein isolate blend films. Lwt-Food Science and Technology, 59(1), 94-100.

Li, M., Xie, F., Hasjim, J., Witt, T., Halley, P. J., \& Gilbert, R. G. (2015). Establishing whether the structural feature controlling the mechanical properties of starch films is molecular or crystalline. Carbohydrate Polymers, 117, 262-270.

Liu, Z., \& Han, J. (2005). Film-forming characteristics of starches. Journal of Food Science, 70(1), E31-E36.

Lopez, O., Garcia, M., Villar, M., Gentili, A., Rodriguez, M., \& Albertengo, L. (2014). Thermo-compression of biodegradable thermoplastic corn starch films containing chitin and chitosan. Lwt-Food Science and Technology, 57(1), 106-115. 
Ma, X., Yu, J., \& Ma, Y. (2005). Urea and formamide as a mixed plasticizer for thermoplastic wheat flour. Carbohydrate Polymers, 60(1), 111-116.

Ma, X., Chang, P. R., Yu, J., \& Stumborg, M. (2009). Properties of biodegradable citric acid-modified granular starch/thermoplastic pea starch composites. Carbohydrate Polymers, 75(1), 1-8.

Magalhães, N., \& Andrade, C. (2009). Thermoplastic corn starch/clay hybrids: Effect of clay type and content on physical properties. Carbohydrate Polymers, 75(4), $712-718$.

Mali, S., \& Grossmann, M. V. E. (2003). Effects of yam starch films on storability and quality of fresh strawberries (Fragaria ananassa). Journal of Agricultural and Food Chemistry, 51(24), 7005-7011.

Mariani, P., Allganer, K., Oliveira, F., Cardoso, E., \& Innocentini-Mei, L. (2009). Effect of soy protein isolate on the thermal, mechanical and morphological properties of poly ( $\varepsilon$-caprolactone) and corn starch blends. Polymer Testing, 28(8), 824-829.

Martínez-Camacho, A., Cortez-Rocha, M., Ezquerra-Brauer, J., Graciano-Verdugo, A., Rodriguez-Félix, F., Castillo-Ortega, M., et al. (2010). Chitosan composite films: Thermal, structural, mechanical and antifungal properties. Carbohydrate Polymers, 82(2), 305-315.

Matveev, Y. I., Grinberg, V. Y., \& Tolstoguzov, V. (2000). The plasticizing effect of water on proteins, polysaccharides and their mixtures. Glassy state of biopolymers, food and seeds. Food Hydrocolloids, 14(5), 425-437.

McHugh, T. H. K., \& John, M. (1994). Sorbital versus glycerol-plasticized edible films: Integrated oxygen permeability and tensile property evaluation. Journal of Agricultural and Food Chemistry, 42(4), 841-845.

Mendes, J., Paschoalin, R., Carmona, V., Neto, A. R. S., Marques, A., Marconcini, J., et al. (2016). Biodegradable polymer blends based on corn starch and thermoplastic chitosan processed by extrusion. Carbohydrate Polymers, 137. 452-458.

Nijdam, J., Ibach, A., Eichhorn, K., \& Kind, M. (2007). An X-ray diffraction analysis of crystallised whey and whey-permeate powders. Carbohydrate Research, 342(16), 2354-2364.

Onwulata, C., Konstance, R., Cooke, P., \& Farrell, H. (2003). Functionality of extrusion-texturized whey proteins. Journal of Dairy Science, 86(11), 3775-3782.

Ortega-Toro, R., Jiménez, A., Talens, P., \& Chiralt, A. (2014). Effect of the incorporation of surfactants on the physical properties of corn starch films. Food Hydrocolloids, 38, 66-75.

Park, S.-i., \& Zhao, Y. (2004). Incorporation of a high concentration of mineral or vitamin into chitosan-based films. Journal of Agricultural and Food Chemistry, 52(7), 1933-1939.

Pelissari, F. M., Grossmann, M. V., Yamashita, F., \& Pineda, E. A. G. (2009). Antimicrobial, mechanical, and barrier properties of cassava starch- chitosan films incorporated with oregano essential oil. Journal of Agricultural and Food Chemistry, 57(16), 7499-7504

Pereda, M., Aranguren, M. I., \& Marcovich, N. E. (2008). Characterization of chitosan/caseinate films. Journal of Applied Polymer Science, 107(2), 1080-1090.

Prommakool, A., Sajjaanantakul, T., Janjarasskul, T., \& Krochta, J. M. (2011). Whey protein-okra polysaccharide fraction blend edible films: Tensile properties, water vapor permeability and oxygen permeability. Journal of the Science of Food and Agriculture, 91(2), 362-369.

Ramos, Ó. L., Fernandes, J. C., Silva, S. I., Pintado, M. E., \& Malcata, F. X. (2012). Edible films and coatings from whey proteins: A review on formulation, and on mechanical and bioactive properties. Critical Reviews in Food Science and Nutrition, 52(6), 533-552.

Raquez, J.-M., Nabar, Y., Srinivasan, M., Shin, B.-Y., Narayan, R., \& Dubois, P. (2008). Maleated thermoplastic starch by reactive extrusion. Carbohydrate Polymers, 74(2), 159-169.

Redl, A., Morel, M. H., Bonicel, J., Guilbert, S., \& Vergnes, B. (1999). Rheological properties of gluten plasticized with glycerol: Dependence on temperature, glycerol content and mixing conditions. Rheologica Acta, 38(4), 311-320.

Rouilly, A., Orliac, O., Silvestre, F., \& Rigal, L. (2001). DSC study on the thermal properties of sunflower proteins according to their water content. Polymer, 42(26), 10111-10117.

Sanchez-Gonzalez, L., Chafer, M., Chiralt, A., \& Gonzalez-Martinez, C. (2010). Physical properties of edible chitosan films containing bergamot essential oil and their inhibitory action on Penicillium italicum. Carbohydrate Polymers, 82(2), 277-283.
Sarantópoulos, C. I., de Oliveira, L. M., Padula, M., Coltro, L., Alves, R. M. V., \& Garcia, E. E. C. (2002). Embalagens plásticas flexíveis: Principais polímeros e avaliação de propriedades. CETEA/ITAL.

Schmid, M., Dallmann, K., Bugnicourt, E., Cordoni, D., Wild, F., Lazzeri, A., et al. (2012). Properties of whey-protein-coated films and laminates as novel recyclable food packaging materials with excellent barrier properties. International Journal of Polymer Science, 2012.

Sensing, K. M. (2007). Precise color communication: Color control from perception to instrumentation. Konica Minolta Sensing, Incorporated.

Shah, P. B., Bandopadhyay, S., \& Bellare, J. R. (1995). Environmentally degradable starch filled low density polyethylene. Polymer Degradation and Stability, 47(2), $165-173$.

Shamekh, S., Myllärinen, P., Poutanen, K., \& Forssell, P. (2002). Film formation properties of potato starch hydrolysates. Starch-Stärke, 54(1), 20-24.

Sharma, S., \& Luzinov, I. (2013). Whey based binary bioplastics. Journal of Food Engineering, 119(3), 404-410.

Shaw, N., Monahan, F., O'riordan, E., \& O'sullivan, M. (2002). Physical properties of WPI films plasticized with glycerol, xylitol, or sorbitol. Journal of Food Science, 67(1), 164-167

Shi, R., Liu, Q., Ding, T., Han, Y., Zhang, L., Chen, D., et al. (2007). Ageing of soft thermoplastic starch with high glycerol content. Journal of Applied Polymer Science, 103(1), 574-586.

Shi, R., Bi, J., Zhang, Z., Zhu, A., Chen, D., Zhou, X., et al. (2008). The effect of citric acid on the structural properties and cytotoxicity of the polyvinyl alcohol/starch films when molding at high temperature. Carbohydrate Polymers, 74(4), 763-770.

Silva, W. A., Pereira, J., Carvalho, C. W. P., \& Ferrua, F. Q. (2007). Determinação da cor, imagem superficial topográfica e ângulo de contato de biofilmes de diferentes fontes de amido. Ciênc Agrotec., (Impr.), 31(1), 154-163.

Sun, Q., Sun, C., \& Xiong, L. (2013). Mechanical, barrier and morphological properties of pea starch and peanut protein isolate blend films. Carbohydrate Polymers, 98(1), 630-637.

Tadmor, Z., \& Gogos, C. G. (2013). Principles of polymer processing. John Wiley \& Sons.

Teixeira, E., Da Roz, A., Carvalho, A., \& Curvelo, A. (2007). The effect of glycerol/sugar/water and sugar/water mixtures on the plasticization of thermoplastic cassava starch. Carbohydrate Polymers, 69(4), 619-624.

Teixeira, E. M., Lotti, C., Corrêa, A. C., Teodoro, K. B., Marconcini, J. M., \& Mattoso, L. $\mathrm{H}$. (2011). Thermoplastic corn starch reinforced with cotton cellulose nanofibers. Journal of Applied Polymer Science, 120(4), 2428-2433.

Wang, N., Zhang, X., Han, N., \& Bai, S. (2009). Effect of citric acid and processing on the performance of thermoplastic starch/montmorillonite nanocomposites. Carbohydrate Polymers, 76(1), 68-73.

Wang, Y., Chang, C., \& Zhang, L. (2010). Effects of freezing/thawing cycles and cellulose nanowhiskers on structure and properties of biocompatible starch/PVA sponges. Macromolecular Materials and Engineering, 295(2), 137-145

Yan, Q., Hou, H., Guo, P., \& Dong, H. (2012). Effects of extrusion and glycerol content on properties of oxidized and acetylated corn starch-based films. Carbohydrate Polymers, 87(1), 707-712.

Zhong, Y., Song, X., \& Li, Y. (2011). Antimicrobial, physical and mechanical properties of kudzu starch-chitosan composite films as a function of acid solvent types. Carbohydrate Polymers, 84(1), 335-342.

Zhou, P., \& Labuza, T. P. (2007). Effect of water content on glass transition and protein aggregation of whey protein powders during short-term storage. Food Biophysics, 2(2-3), 108-116.

Zullo, R., \& Iannace, S. (2009). The effects of different starch sources and plasticizers on film blowing of thermoplastic starch: Correlation among process, elongational properties and macromolecular structure. Carbohydrate Polymers, 77(2), 376-383.

de Campos, A., Tonoli, G. H., Marconcini, J. M., Mattoso, L. H., Klamczynski, A., Gregorski, K. S., et al. (2013). TPS/PCL composite reinforced with treated sisal fibers: Property, biodegradation and water-absorption. Journal of Polymers and the Environment, 21(1), 1-7.

de Graaf, R. A., Karman, A. P., \& Janssen, L. P. (2003). Material properties and glass transition temperatures of different thermoplastic starches after extrusion processing. Starch-Stärke, 55(2), 80-86. 